Farum

Sociológico

\section{Forum Sociológico}

Série II

28 | 2016

Interculturalidade e educação

\title{
Some Reflections on the educational trajectories of migrant students in the European school systems
}

Breves reflexões sobre as trajectórias educativas de estudantes migrantes nos sistemas escolares europeus

\section{Morena Cuconato}

\section{(2) OpenEdition}

\section{Journals}

Electronic version

URL: https://journals.openedition.org/sociologico/1386

DOI: 10.4000/sociologico.1386

ISSN: 2182-7427

Publisher

CICS.NOVA - Centro Interdisciplinar de Ciências Sociais da Universidade Nova de Lisboa

Electronic reference

Morena Cuconato, "Some Reflections on the educational trajectories of migrant students in the European school systems", Forum Sociológico [Online], 28 | 2016, Online since 31 December 2016, connection on 30 March 2022. URL: http://journals.openedition.org/sociologico/1386 ; DOI: https:// doi.org/10.4000/sociologico.1386 


\title{
SOME REFLECTIONS ON THE EDUCATIONAL TRAJECTORIES OF MIGRANT STUDENTS IN THE EUROPEAN SCHOOL SYSTEMS BREVES REFLEXÕES SOBRE AS TRAJECTÓRIAS EDUCATIVAS DE ESTUDANTES MIGRANTES NOS SISTEMAS ESCOLARES EUROPEUS
}

\author{
Morena Cuconato \\ University of Bologna, Department of Educational Sciences
}

\begin{abstract}
This paper proposes an analysis of the educational trajectories of disadvantaged students, among them migrant ones, at the transition point from lower secondary into upper secondary school/ vocational education, i.e., the age group between 10 and 16 years. The data were collected in the European project "Governance of Educational Transition in Europe - GOETE". The main aim of this paper is to present the interactive aspect of students' transitions in order to spot some different lights to the quantitative studies stating the serious migrant educational underachievement mainly attributed to structural causes. Instead, the findings of GOETE project highlight the interplay between socio-economic structures and family resources, institutional pathways and support provided by education (and welfare) systems, and the subjective motivation and orientation of the young people. Confronted with a transition demand, migrant students' possibility to act and make their own choices is structured differently.
\end{abstract}

Keywords: migrant students, educational trajectories, transition, educational inequality

\section{Resumo}

Este artigo propõe uma análise das trajectórias escolares dos alunos desfavorecidos, entre eles os migrantes, na transição do ensino básico para o ensino secundário superior ou o vocacional, entre os 10 e os 16 anos. Os dados foram recolhidos através do projecto europeu "Governance of Educational Transition in Europe - GOETE". O objectivo principal é apresentar a dimensão interactiva das transições dos alunos, realçando alguns aspectos em estudos quantitativos que apontam para um sério subaproveitamento escolar dos migrantes devido a causas estruturais. Ao invés, os resultados do projecto GOETE destacam a interacção entre as estruturas socioeconómicas e os recursos familiares, os percursos institucionais e o apoio dos sistemas de educação (e de bem-estar), e a motivação e orientação subjectiva dos jovens. Confrontados com a transição, a possibilidade de os estudantes migrantes agirem e fazerem as suas próprias escolhas é estruturada de forma diferente.

Palavras-chave: estudantes migrantes, trajectórias escolares, transição, desigualdade escolar

\section{Introduction}

International assessments on students' competencies show a serious migrant educational underachievement that differs across European countries (Schnepf, 2007). While Fossati (2011), Schneeweis (2011), and Dustmann et al. (2012) find no significant differences between migrant and native students in Britain and non-European "old" migration countries, in
Nordic and Continental Europe the achievement gaps are significant, perhaps due to language acquisition problems. Furthermore, with the aim of contrasting the hypothesis of an "ethnicisation" of the gap, Crul et al. (2012) show that migrant educational disadvantage differs across countries even when examining the same (Turkish) minority group.

Sociological research on ethnic educational inequality has identified home resources, parental 
class, and cultural capital as the micro-level determinants explaining the educational disadvantage of migrant student (Kristen and Granato, 2007; Van De Werfhorst and Van Tubergen, 2007). However, some authors (Hanushek and Woessmann, 2011) attach to the different structures of the educational system the missing migrant students' possibility to overcome their initial disadvantage. In the GOETE project, we combined these two hypotheses.

With the aim of nuancing the phenomenon of migrant students' underachievement, in this article I start from the assumption that the learning processes and not the learning outcomes can spot lights on the reasons of this underachievement. The mainstreaming use of the umbrella category "migrant student" risks either to hidden or to generalize the individual experiences, every-day life and future expectations that have a deep influence on students' possibility to cope with the school requirements. Therefore, there is the need of an interactive approach that pays attention both to the institutional features of the different education systems and to the individual traits of (migrant) students' educational trajectories. After introducing the main concepts framing the theoretical approach and the methodology of this paper partially reproducing that of the GOETE project, I present the five clusters of educational trajectories emerging from the data and two exemplary learning biographies of migrant students highlighting the individual motivational factors that make them evolving differently. The end section proposes a discussion of the finding.

\section{Theoretical framework}

The insight that public education is a major factor structuring individual life course trajectories is widely acknowledged. Social and educational researches have focussed on the reproduction of social inequality in and through education in general as well as on variations across different education systems (Allmendinger, 1989; Bourdieu and Passeron, 1977; Mayer, 1997; OECD, 2001). Since the 1990 s, public and policy discourses have increasingly referred to education as lifelong learning and human capital as factors of economic growth and social cohesion. A key concern in this regard has been the reduction of early school leaving (Nesse, 2009). "Early" and "(life)long" refer clearly to the concept of life course implied in such discourses. Despite the apparent self-evidence and relevance of this relationship, there are many aspects, which are still under-researched and neglected by research and public discourse like for example the separation between education and life course. Education tends to be dealt with as an input factor of individual socialisation processes determining outcomes in later life. In between it seems to be a black-box
(Kelly, 2012) and this regards particularly the life of migrant students.

Trying to replace this dichotomist view, I propose an interconnected approach to life course and education, complementing the question about the effects of education on the life course with questions about the effects of the life course on education both in terms of education as an institution and as processes of individual learning and development. Therefore, the progression, performance and experiences of children and young people in education are considered as integral parts of their life courses. This paper deals with the educational trajectories of children and young people in lower secondary education, from the end of primary education to entry into upper secondary education and vocational training. The focus is on the complex constellations of structure and agency at this very special point that in many cases coincides with the end of compulsory schooling and confronts students with new (adult) expectations, status and practices having a long-term effect on their future life course.

The concept of educational trajectories refers to how individuals proceed through different educational stages, how they combine them with other life spheres, how they cope with transitions and how they take decisions regarding their educational career. Individual educational processes and life course trajectories should be understood in terms of a dynamic and dialectic relationship between structure and agency (Emirbayr and Mische, 1998; Giddens, 1984), that is to say between institutionalised life course and subjective biography. Educational trajectories are embedded in social structures providing individuals with different resources and opportunities while at the same time resulting from individual decision-making and complex interactions between students and other actors. Progressing through school implies an institutionally defined role and career and at the same time represents an integral part of student biographies (Heinz et al., 1996; Helsper et al., 2008). While school careers are standardised and structured by curricula, teaching and assessment, school biographies are individual and structured by subjective meaning and the need for coherence between school and other aspects of life.

Another key aspect that adds to the complexity of educational trajectories is that the time children and young people spend in the education system is not always as linear and homogeneous as suggested. School entry, changes between school levels and exit from school education represent major transitions, which can proceed more or less successfully having consequences for the individual self-concept as student. However even within stages of school attendance there are transitions like changing school due to moving house, a very frequent experience for what concerns migrant students, repeating 
school years (in some education systems), being stigmatised as a (migrant) underachieving student, or being downgraded to a school of lower status. All these factors - some more visible and evident than others - impact on the educational course and broaden or narrow future life chances.

Therefore, analysing transitions implies taking into account three dimensions: the institutional, individual and interactive. This last regards the involvement of key actors in educational decision-making at transition point. This perspective is central to avoid the trap of methodological individualism, which is to reduce decisions to individual (rational) choice or structural determinism assuming an automatism between structural conditions and individual decision-making, which is the main shortcoming of many studies on migrant students' underachievement.

\section{Methodology and empirical data}

This article grounds on empirical data from a sub-project carried out in the eight countries participating in the GOETE Project: Germany, Finland, France, Italy, the Netherlands, Poland, Slovenia and the UK. Qualitative case studies in three cities per country were conducted in disadvantaged "local school spaces" (Maroy, 2004), which includes also extra- school educational actors as well as extra-curricular learning opportunities integrating or complementing the school curriculum which can therefore affect the educational trajectories of young people.

In order to reconstruct the interactive nature of students' educational trajectories, the case studies involved students, parents, teachers, principals and local policy makers. Data were gathered from group discussions with students and teachers, individual in-depth interviews with parents $(\mathrm{N}=109)$ as well as with students during $(\mathrm{N}=195)$ and after they had left lower secondary education ( $\mathrm{N}=109)$, reconstructing their trajectories up to entering the post-compulsory stage. These interviews were analysed in order to compare the different views of the actors and reconstruct interactive constellations. The coding process was composed by a combination of qualitative content analysis and grounded theory and combined open coding with the development of a joint code tree built from the open codes developed by the different national teams.

Although designed as an international comparative study, GOETE data do not allow for a comparative analysis in a representative sense as the samples are not representative and the data were collected at different time points. Comparative analyses in the GOETE project therefore rely on interpretation by contextualising specific findings with regard to different cultural and structural contexts. Nevertheless, reference has been made to existing comparative typologies first as a rationale for the comparative sampling of differing national contexts and second as an interpretative framework that helps explain differences and similarities (Walther et al., 2009).

We adopted the typology developed by Allmendinger (1989) who analyses education systems according to the key dimensions of stratification and standardisation. Stratification refers to the way and the extent to which differentiated routes through education lead to different outcomes, i.e. qualifications of unequal status. Standardisation refers to the way and degree to which contents and qualifications of education are regulated and recognised.

For the GOETE research, this typology is relevant for understanding the relationship between education and later life course, access to and within education, the labour market value of education, and mechanisms of educational governance. The resulting typology distinguishes four ideal types, three of which are covered by countries in the GOETE project.

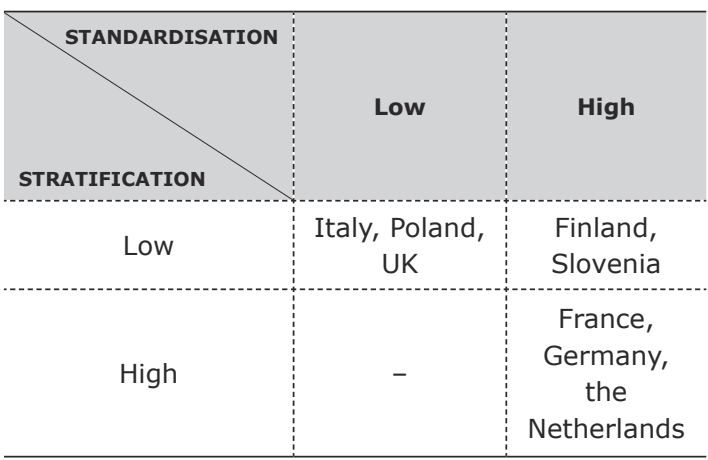

Table $1 \triangleright$ Categorisation of countries; based on Allmendinger's typology (1989)

Moreover, in order to address the relevance of education, a biographical perspective is needed, and has to be linked with given or withheld support inside and outside school. The model of transition regimes (Walther, 2006) combines Allmendinger's typology with the model of welfare regimes of Esping-Anderson (1990), and includes youth-specific dimensions such as young people's access to social security, orientations of policies for unemployed youth as well as dominant cultural meanings of disadvantage and youth. This model also distinguishes four types, which are covered by GOETE countries. The types, however, do not apply to post-socialist countries like Poland and Slovenia (see table 2).

Combining this two typology in the analysis of the finding should provide a more comprehensive insight into how social inequality is constructed and reproduced through overall discourses, institutional regulation, formal and informal support, individual decision-making and - above all - com- 
Table $2 \triangleright$ GOETE countries according to youth transition regimes

\begin{tabular}{|c|c|c|c|c|c|}
\hline Regime type & School & Training & Welfare & Disadvantage & Youth \\
\hline Universalistic (FI) & Comprehensive & Standardised & State & $\begin{array}{l}\text { Individual/ } \\
\text { /Structural }\end{array}$ & $\begin{array}{l}\text { Personal } \\
\text { development }\end{array}$ \\
\hline Liberal (UK) & Comprehensive & Non-standardised & State/family & Individual & $\begin{array}{l}\text { Economic } \\
\text { independence }\end{array}$ \\
\hline $\begin{array}{l}\text { Employment-centred } \\
(\mathrm{D}, \mathrm{FR}, \mathrm{NL})\end{array}$ & Selective & Standardised & State/family & Individual & $\begin{array}{l}\text { Vocational } \\
\text { socialisation }\end{array}$ \\
\hline Under-institutionalised (IT) & Comprehensive & Non-standardised & Family & Structural & $\begin{array}{l}\text { Status vacuum } \\
\text { (dependency) }\end{array}$ \\
\hline $\begin{array}{l}\text { Post-socialist countries } \\
(P L, S I)\end{array}$ & Comprehensive & Variable & State/family & $\begin{array}{l}\text { Individual/ } \\
\text { /Structural }\end{array}$ & Variable \\
\hline
\end{tabular}

plex interaction between different levels and actors rather than following one-dimensional causalities. Its comparative dimension allows differentiating between general dimensions and factors involved in the emergence of educational trajectories and their particular expressions in the context of different national education systems and welfare states. In the next section, we shortly present the main findings resulting from the analysis of case studies. As our specific focus is on students with a migrant background, we present their cases more in details through two individual examples.

\section{Diversity of educational trajectories}

The qualitative analysis of the 106 in-depth interviews with young people attending schools located exclusively in disadvantaged contexts was made reconstructing their trajectories according both to structural aspects (especially socio-economic status, gender, migration or ethnic minority background but also institutional structures of the education system) and to individual agency. Interviews were structured by an open beginning allowing for a biographical narrative followed by a series of topics addressed in all interviews to allow for comparison. Both perspectives were interrelated in the dimensions of earlier ruptures, destinations after lower secondary education, and degrees of choice. Operationalising educational trajectories in terms of ruptures, destinations and choice implies a crude reduction of complexity, however it served as a heuristic means to distinguish different patterns without neglecting the tension between social structure and individual agency. All the steps of the 106 educational trajectories were clustered in a matrix according to the above-mentioned categories from which five main patterns emerged:

1. Smooth academic: linear progression into general upper secondary school without ruptures and in correspondence with one's own preference;
2. Smooth vocational: linear progression into vocational upper secondary education or training without ruptures and in correspondence with own one's preference;

3. Discontinuous academic: trajectory into general upper secondary education after earlier ruptures and/or requiring compromising one's own preferences;

4. Discontinuous vocational: trajectory into vocational upper secondary education or training after earlier ruptures and/or requiring compromising one's own preferences;

5. Intermediate or remedial: trajectory leading into pre-vocational schemes or preparatory courses after previous ruptures and against one's own preference.

Despite the non-representativeness of the sample, it becomes obvious that patterns are partly structured by education systems. In comprehensive school systems migrant students display smooth trajectories into upper general or vocational education while discontinuous patterns are closely related to the selection mechanisms in differentiated systems, especially in Germany and the Netherlands. In the following I show in more detail the individual interplay of factors involved in two migrant students' trajectory contrasting a selective and a comprehensive education system in order to show the two different "windows of opportunity".

Ron lives together with his parents and his sister in Rotterdam (Netherlands). His father (Dutch) works as administrative employee, his mother (Surinamese) stays at home. At the time of the interview, he has already 18 years of age due to ruptures in his school career. It was "quite a dramatic period", because he was bullied most of the time in primary school. Neither teachers nor pupils helped him: "Otherwise I would have had a better youth and would have attended school with much more pleasure".

After primary school, he was advised to attend a special school for students with learning difficulties and behavioural problems although no test was made. 
Table $3 \triangleright$ Trajectory of Ron (NL) into vocational education or training (discontinuous vocational)

\begin{tabular}{|c|c|c|c|c|c|c|}
\hline $\begin{array}{c}\text { Family } \\
\text { and social } \\
\text { background }\end{array}$ & $\begin{array}{l}\text { Primary } \\
\text { school }\end{array}$ & $\begin{array}{l}\text { Transition to } \\
\text { lower-secondary }\end{array}$ & $\begin{array}{l}\text { Lower } \\
\text { secondary }\end{array}$ & $\begin{array}{l}\text { Transition to } \\
\text { post-compulsory }\end{array}$ & $\begin{array}{c}\text { Support } \\
\text { experience }\end{array}$ & $\begin{array}{l}\text { Post- } \\
\text { compulsory } \\
\text { stage }\end{array}$ \\
\hline $\begin{array}{l}\text { Migration } \\
\text { background, } \\
\text { difficult } \\
\text { area, } \\
\text { segregated } \\
\text { schools }\end{array}$ & $\begin{array}{l}\text { Experience } \\
\text { of bullying }\end{array}$ & $\begin{array}{l}\text { First years in } \\
\text { special school } \\
\text { (on school } \\
\text { advice without } \\
\text { test) }\end{array}$ & $\begin{array}{l}\text { After } 3 \text { years } \\
\text { transition } \\
\text { to lower } \\
\text { vocational } \\
\text { school } \\
\text { implying } 2 \\
\text { years more } \\
\text { than normally }\end{array}$ & $\begin{array}{l}\text { Vocational } \\
\text { school in } \\
\text { business } \\
\text { management } \\
\text { following advice } \\
\text { of friends and } \\
\text { parents }\end{array}$ & $\begin{array}{l}\text { Primarily } \\
\text { parents, } \\
\text { negative } \\
\text { experience of } \\
\text { institutional } \\
\text { support }\end{array}$ & $\begin{array}{l}\text { Intends to } \\
\text { continue } \\
\text { as high as } \\
\text { possible in } \\
\text { this strand }\end{array}$ \\
\hline
\end{tabular}

He regrets having lost two years as, according to himself, he was not a bad student. Nevertheless, he appreciates the time in that school where he regained self-confidence: "I changed completely. If that had not happened I might not even be able to have this interview and to care for myself".

After three years, he passed on to regular lower vocational school (still a school of low status) where he is again allocated on a low level: "I told them that I found it too easy but they thought that I did not do well enough and when I got good marks but sometimes a bad mark, they took that as proof". In this school, he tried not to be associated with bad students. He did not mind being referred to as a "nerd", he wanted to learn. He achieves a lower secondary vocational qualification in trade and administration.

After lower secondary education, his parents advised him to choose a sector with safe labour market prospects: "First of all you must have a stable basis". Regarding institutional help he says: "Help is a big word", guidance lectures and open days were "not so relevant". He chose a vocational school for business management relying on recommendations of friends already attending it and because it is close to his home. He was disappointed when he found out that he was again categorised too low. He tried to protest, "right at the beginning so that they might have done something about it", but "they" did not listen. Nevertheless, he did not lower his aspirations. He has developed the intention to finish this course in less time than foreseen. He likes the new school - a new start, nice new fellow students and teachers. The biggest difference is that students behave as grown-ups.

In the future, he wants to get "as many diplomas as possible" and to become "a rich man" able to support his parents. Regarding his chances, Ron appears realistic, it can always turn out differently from what you wanted, but he is not pessimistic either.

Ronaldo lives in a Roma settlement in Murska Sobota (Slovenia) with his elderly and unemployed mother. During primary and lower secondary school he experienced discrimination. He admits that he caused problems due to his "playful" attitude but also felt treated as the "scapegoat on duty". His decision to enrol in a medical upper secondary school is inspired by TV medical series which he likes a lot, and by his cousin who graduated from the same course. His mother is very ambitious and expects him to avoid a low status vocational career. Therefore, he decided to enrol in the present school despite the teachers' recommendations to enrol in a vocational school due to his poor final testing at the end of lower secondary school. Although he knows that the current course may be too difficult and demanding for him due to his bad working habits, he affirms: "this is my choice, I really don't care what other think about it". However, after a few months he is already considering the option of changing to a shorter medical programme or - following the advice of another cousin - even to a vocational school for

Table $4 \triangleright$ Trajectory of Ronaldo (Slovenia) into a (smooth) academic trajectory.

\begin{tabular}{|c|c|c|c|c|}
\hline $\begin{array}{l}\text { Family and social } \\
\text { background }\end{array}$ & $\begin{array}{l}\text { Comprehensive } \\
\text { compulsory education }\end{array}$ & $\begin{array}{l}\text { Transition to post- } \\
\text { compulsory }\end{array}$ & $\begin{array}{c}\text { Support } \\
\text { experience }\end{array}$ & $\begin{array}{l}\text { Post-compulsory } \\
\text { stage }\end{array}$ \\
\hline $\begin{array}{l}\text { Roma minority, } \\
\text { absent father, } \\
\text { unemployed } \\
\text { mother, Roma } \\
\text { settlement }\end{array}$ & $\begin{array}{l}\text { Institutionally } \\
\text { smooth has no } \\
\text { transition between } \\
\text { primary and lower } \\
\text { secondary school. } \\
\text { Individual problems: } \\
\text { discrimination, poor } \\
\text { work habitus }\end{array}$ & $\begin{array}{l}\text { General upper } \\
\text { secondary } \\
\text { school with a } \\
\text { medical profile } \\
\text { despite school's } \\
\text { recommendations } \\
\text { for vocational school }\end{array}$ & $\begin{array}{l}\text { Cousins as role } \\
\text { models, little } \\
\text { support from } \\
\text { parents and high } \\
\text { mother's pressure }\end{array}$ & $\begin{array}{l}\text { Ambivalent attitude } \\
\text { swinging between the } \\
\text { ambition of finishing } \\
\text { the present school } \\
\text { or switching to car } \\
\text { mechanic }\end{array}$ \\
\hline
\end{tabular}


car mechanics, if he does not perform well. At the end of the interview, he stresses again the will to finish the present school "I trust myself; I think I will finish [this] school". It remains uncertain whether his personal desires and ambitions are strong enough to make up for the disadvantages resulting from his minority status, his lack of family support and his diffidence towards institutions.

\section{Concluding remarks: migrant students in transition under conditions of disadvantage and inequality}

The empirical analysis seems to confirm the hypothesis that in comprehensive schools, as opposed to selective systems, students are less at risk of failing due to institutionalised transitions and cooling out mechanisms. As Ronaldo attends the comprehensive Slovenian school, his trajectory to upper-secondary education is smooth in comparison with that of Ron. However, the experience of being the "scapegoat on duty" makes him mistrusting teachers and educators. His attitude swings between an apparent self-confidence and the awareness of the need of a "plan b" to develop in case of failure. While Ron has developed a more realistic vision of the space of action that the system gives him and he is ready to struggle as much as he can for moving successful within it, Ronaldo develop his plan according to his mother's ambition and his naïve interest for the medical profession. He looks for role models within the family; he look at both his male cousins independently from their field of work: it seems that for him is more important to have someone to follow than to develop an own interest. However, it must be said that Ronaldo is four years younger than Ron is and in Slovenia the selection processes starts in upper secondary education. This could also explain the different parental advises. In the case of Ron, he and his parents has already experienced the institutional constraints that make them having a pragmatic approach towards education; in the case of Ronaldo, instead, the ambitious mother has seen his son proceeding smooth though education and therefore she develops higher expectation pressuring him to enrol in the highest track of education. This observation is common to other parents with migrant origin: in the countries with less selective systems, they develop for their children plans that are more ambitious than in the selective ones, stressing them to follow the highest path, independently from their interests and learning attitude.

Coming back to Ron, it is important to underline that his trajectory reflects a series of factors found also in other discontinuous and/or compromised trajectories into vocational education or training, the two clusters in which we found the majority of students with a migrant background (21 out of 34$)^{1}$. One factor is the experience of bullying, which was not dealt with adequately in school by placing him in a special school; the individual pays for the systemic inadequacy of the school. This means that in case of underachievement or problematic behaviours students either are tracked in a stigmatized vocational route (without continuation towards higher education) or are segregated in special needs schools instead of being institutionally supported. Segregation also applies in socio-economic terms as Ron characterises his educational trajectory structured by schools with a high share of students from disadvantaged backgrounds and a climate of stigmatisation, de-motivation and resistance. However, Ron develops a struggling attitude and a clear prospect of his future priorities that makes him ready to resist to these constraints. Many migrant students in these clusters apparently succeed in re-interpreting disadvantage as challenges they feel able to meet. They share the ability to keep their educational and professional plans alive despite of adverse circumstances and to mobilize different kinds of support.

These two exemplary learning biographies should have demonstrated that education systems alone do not explain all differences in educational trajectories at transitions' moments. Transitions are "done" and processed in an interactive way through negotiation and struggle between different actors at different levels. This regards especially the trajectories of young people with a migrant background whose parents are less confident with the education system of the host country and often compelled to follow work moving around countries, cities or areas causing ruptures in the educational trajectories of their offspring. The analysis of patterns of trajectories reveals that also under conditions of social disadvantage individual cases differ with regard to existing "windows of opportunity" towards different directions, at different moments and depending on different actors. Understanding small-scale interaction is necessary to extend the knowledge that socio-economic structures of inequality, as well as institutional structures of selectivity, make a difference to how these mechanisms work instead of generalising the stigmatizing discourse of migrants students as underachievers.

\section{Notes}

111 of the 21 students in these two discontinuous and or compromised trajectories attended German and Dutch schools (selective systems) while the other 10 were schooled in the other six countries participating to the project (FI,FR, IT, PL, SL, UK) 


\section{References}

ALLMENDINGER, J. (1989), "Educational Systems and Labour Market Outcomes", European Sociological Review, 5, pp. 231-250.

BOUDON, R. (1974), Education, Opportunity and Social Inequality, New York, Wiley.

BOURDIEU, P. and J.-C. Passeron (1977), Reproduction in Education, Society and Culture, London, Sage.

CRUL, M.; J. Schneider and F. Lelie (ed.) (2012), The European Second Generation Compared. Does the Integration Context Matter?, Amsterdam, Amsterdam University Press.

DUSTMANN, C.; T. Frattini and G. Lanzara (2012), "Educational Achievement of Second-Generation Immigrants: An International Comparison", ECOnomic Policy, 27, pp. 143-185.

EMIRBAYER, M. and A. Mische (1998), "What is Agency?", American Journal of Sociology, 103 (4), pp. 962-1023.

ESPING-ANDERSEN, G. (1990), The Three Worlds of Welfare Capitalism, Princeton, Princeton University Press.

FOSSATI, F. (2011), "The Effect of Integration and Social Democratic Welfare States on Immigrants' Educational Attainment: a Multilevel Estimate", Journal of European Social Policy, 21, pp. 391-412.

GIDDENS, A. (1984), The Constitution of Society. Towards a Theory of Structuration, Cambridge, Policy Press.

HANUSHEK, E. A. and L. Woessmann (2011), "The Economics of International Differences in Educational Achievement", in E. Hanushek, S. Machin and L. Woessmann (eds.), Handbook of the Economics of Education, Oxford, Elsevier, pp. 89-200.

HEATH, A.; C. Rothon and E. Kilpi (2008), "The Second Generation in Western Europe: Education, Unemployment, and Occupational Attainment", Annual Review of Sociology, 34, pp. 211-235.

HEINZ, W.; A. Weymann and P. Alheit (eds.) (1996), Society and Biography: Interrelationships between Social Structure, Institutions, and the Life Course, Weinheim, Deutscher Studienverlag.

HELSPER, W.; R.-T. Kramer; S. Brademann and C. Ziems (2008), "Children's Biographical Orientations
Toward Selection Procedures at School", in G. Foljanty-Jost, W. Helsper, H.-H. Krüger, M. Hummrich and R.-T. Kramer (eds.), Family, Youth, and School Culture, Frankfurt, Peter Lang, pp. 179-198.

KELLY, P. (2012), "The Brain in the Jar: A Critique of Discourses of Adolescent Brain Development", Journal of Youth Studies, 15 (7), pp. 944-959.

KRISTEN, C. and N. Granato (2007), "The Educational Attainment of the Second Generation in Germany Social Origins and Ethnic Inequality", Ethnicities, 7, pp. 343-366.

MAROY, C. (2004), Regulation and Inequalities in European Education Systems, Research report.

MAYER, K.-U. (1997), "Notes on a Comparative Political Economy of Life Courses", Comparative Social Research, 16, pp. 203-226.

NESSE (Network of Experts of Social Sciences in Education and Training) (2009), Early School Leaving: Lessons from Research for Policy Makers. Download: www.nesse.fr

OECD (2001), Knowledge and Skills for Life: First Results from PISA 2000, Paris, OECD.

SCHNEEWEIS, N. (2011), "Educational Institutions and the Integration of Migrants", Journal of Population Economics, 24, pp. 1281-1308.

SCHNEPF, S. (2007), "'Immigrants' Educational Disadvantage: An Examination across Ten Countries and Three Surveys", Journal of Population Economics, 20, pp. 527-545.

VAN DE WERFHORST, H. G. and F. Van Tubergen (2007), "Ethnicity, Schooling, and Merit in the Netherlands", Ethnicities, 7, pp. 416-444.

WALTHER, A. (2006), "Regimes of Youth Transitions. Choice, Flexibility and Security in Young People's Experiences across Different European Contexts", Young, 14 (1), pp. 119-141.

WALTHER, A. (2009), "It Was Not My Choice, You Know? Young People's Subjective Views and DeCision Making Processes in Biographical Transitions", in I. Schoon and R. Silbereisen (eds.), Transitions from School to Work: Globalisation, Individualisation and Patterns of Diversity, Cambridge, Cambridge University Press, pp. 121-145.

Recebido a 31/05/2016. Aceite para publicação a 07/10/2016.

Morena Cuconato (morena.cuconato@unibo.it). University of Bologna, Department of Educational Sciences. Via Filippo Re 6, 40126, Bologna, Italy. 